Doi: HTTPS://DOI.ORG/10.23910/2/2020.0376

\title{
Farmers Perception towards Agri-clinical Services for Rubber Plantation Crop at Sepahijala District of Tripura
}

\author{
Piyush Mehta*, Chayan Mani Debbarma, Krishan Kumar Raina and Neha Kashyap
}

Dept. of Business Management, Dr Yashwant Singh Parmar University of Horticulture and Forestry, Nauni, Solan H.P. (173 230) India

\section{Corresponding Author}

Piyush Mehta

e-mail: piyushabm@gmail.com

\author{
Article History \\ Article ID: IJEP0376 \\ Received in $10^{\text {th }}$ April, 2020 \\ Received in revised form $21^{\text {st }}$ May, 2020 \\ Accepted in final form 04 ${ }^{\text {th }}$ June, 2020
}

\begin{abstract}
This study aims to access and evaluate the Farmers perception towards Agri-clinical services of the rubber crop. The study has taken readings on the basis of their awareness level towards clinical services, the perception regarding clinical services, the significance of issues during the application of clinical services and some suggestive opinions of farmers located at Sepahijala district of Tripura. Study has highlighted the level of awareness and knowledge among farmers for clinical services to be used for rubber plantation crop. The study has highlighted that the subsidies will increase more development in their purchasing capacity like equipment and tools and also it will lead to more participation in rubber farming. It has been categorically identified the core significance of clinical services among the key stakeholders of the plantation crop. Paper has made an attempt to find out the utilization of farm utility, schemes, proper handling of inputs and risk management functions of commodity.
\end{abstract}

Keywords: Farmers perception, plantation crop, purchasing capacity, rubber farming

\section{Introduction}

The North eastern state, Tripura is fortunate enough that it has been gifted by nature an agro-climatic condition which is suitable for Hevea brasiliensis (rubber) for cultivation. This opportunity needs to be utilised for socio-economic development of the state. The Bishalgarh block of Sepahijala district, Tripura, India is characterized by humid subtropical climate and also represents undulating topography (325\% slopes). Hilly soils are very prone to degradation and pose a serious threat to agricultural productivity. Rubber cultivation in Bishalgarh block of Sepahijala district, Tripura was moderately suitable in the undulating plains and uplands without forest (Bandyopadhay et al., 2018). The Hevea brasiliensis (Rubber) have created a significant platform in the income generation for the producers and it also leads to contribute in the GDP of Tripura. It also introduced as a mode of afforestation drive in the early 1960s. The sector was attributed by the efforts of various augmenting agencies like Rubber Board, Tripura Forest Development and Plantation Corporation Ltd. (TFDPC) and Tripura Rehabilitation Plantation Corporation Ltd. (TRPC). It also shows that the real wages of the tappers are lesser than that of the agricultural and unskilled labourers. It is important for the state to have an assessment on the labour requirement as more and more rubber plantations of Tripura are reaching the stage for tapping, which requires sustained flow of rubber tappers or else the potential of the sector can never be realised and this perceived engine of growth will slow down (Chouhan and Bhowmik, 2017). The farmers who are having smaller size of holdings to run rubber enterprise are more active on better adoption of the plantation technology. Smaller plantations mean high intensity management, are more dynamic display of modernizing enterprise through the adoption of technologies. It indicates that the socio-economic variables like age, education, homestead land; own land and area under rubber cultivation had become the predominant factors in adopting the recommended technology packages (Reang et al., 2104). Intercropping of rubber with food crops has found to be a solution for the production constraint in most rubber producing countries. Policy makers, researchers and extension providers have closely work together with rubber farmers in identifying suitable rubber plantation spacing and varieties on a case by case basis to ensure effective adoption and scaling out (Tetteh et al., 2019).

The major problem facing the cultivation of rubber in developing countries is the destructive effect of the pathogens which result in about $50 \%$ loss in crop yield and various operational and logistic challenges. The disease symptoms presented in categories from a JAVA based user friendly 
graphical interface and suggests curative and preventive measures of it. The diagnosis of the crop was able to reveal the causes, prevention and the resultant disease of the rubber crop (Konyeha and Imouokhome, 2018).The straw-based composites demonstrated that cereal straw waste could be used as an alternative, biodegradable and eco-friendly reinforcement of natural rubber composites. The use of cheap and renewable raw material to strengthen the elastomer matrix contributed to the creation of an extensive secondary filler structure in the polymer, which was confirmed by dynamic mechanical analysis (Masłowski et al., 2019).The specialization and competitiveness of natural rubber production is related to natural conditions, market demand and technological development and with the lowest production costs. Therefore, it is necessary to promote a regional innovation system for the design and implementation of smart specialization strategies (Vargas-Canales et al., 2019).

\section{Materials and Methods}

The descriptive research design was adopted for the concerned research study. The research was conducted at Sepahijala district of Tripura in 2020. After the district selection, two blocks were selected from the district and from there 3 villages from each block were chosen for the study. The sampling was done over a total number of 120 rubber growing farmers where 20 respondents from each village are randomly selected for the study observation. Two types of data were collected for the study. Primary data was collected through closed ended structured interview schedule. The questionnaire was divided into two parts. Part ' $A$ ' was designed to seek information on the demographic variables such as name, gender, age, income etc. Part ' $B$ ' consisted of general views and statements based on Likert scale to evaluate farmers perception towards benefits, problems and prospects of clinical services for rubber plantation crop. Secondary data was taken from journals, magazines, research articles, newspaper, and books. Simple mathematical and statistical tools including Arithmetic Mean, Standard Deviation, \%age and Total Weightage Score method were used for satisfying the objectives with a view of keeping the analysis simple and easy to understand. The concerned study was initiated with the key objective, to study the awareness level of rubber producing farming community towards various agri-clinical services, to evaluate the perceptual mapping of rubber producing farmers on the facilities extended by agri-clinical agencies, to highlight various clinical issues faced by rubber growers and also to seek suggestive opinion for improving agri-clinical Facilities and to identify the areas of existing rubber plantations in the state and the impact of targets set by agri-clinics involve with Rubber plantation and production.

\section{Results and Discussion}

\subsection{Employment status of the respondents}

Agriculture is the sector that provides job opportunities to the majority sections of the society. The maximum respondents were farmers and involved in rubber farming for their day to day livelihood expenses. It was observed that largely respondents were holding the farming status followed by govt. Service and both dual occupation as the sole employment source and there were fewer respondents who were holding both the employment status together. Thus, considering a mixed set up of employment status, it was observed that farmers were highly inclined to understand and avail the agriclinical services in their respective farming business (Table 1 ).

\begin{tabular}{lll}
\hline \multicolumn{2}{l}{ Table 1: Employment status of the respondents } \\
\hline Employment status & No. of respondents & \%age \\
\hline Govt. Service & 12 & 10 \\
Farmer & 98 & 81.67 \\
Both & 10 & 8.33 \\
Total & 120 & 100 \\
\hline
\end{tabular}

Source: primary probe, 2020

\subsection{Gender status of the respondents}

It was observed that majority of the respondents were males $58.33 \%$ followed by females $41.67 \%$. Female population was also averagely indulged in the rubber farming for sustaining their livelihood (Table 2).

\begin{tabular}{lcc}
\hline \multicolumn{3}{l}{ Table 2: Gender status of the respondents } \\
\hline Gender & No. of respondents & $\%$ age \\
\hline Male & 70 & 58.33 \\
Female & 50 & 41.67 \\
Total & 120 & 100 \\
\hline
\end{tabular}

Source: primary probe, 2020

\subsection{Age of the respondents}

Respondents in the sepahijala district were in between the age group of $31-50$ followed by $21-30$ age group above 50 age group. Highest \%age of respondents belongs to the $31-50$ years of age group (Table 3 ).

\begin{tabular}{lcc}
\hline \multicolumn{2}{l}{ Table 3: Age of the respondents } \\
\hline Age (in years) & No. of respondents & $\%$ age \\
\hline $18-20$ & 0 & 0 \\
$21-30$ & 24 & 20 \\
$31-50$ & 74 & 61.67 \\
Above 50 & 22 & 18.33 \\
Total & 120 & 100 \\
\hline
\end{tabular}

Source: primary probe, 2020

\subsection{Marital status of the respondents}

Maximum no. of the respondents were married and only $10 \%$ of the respondants are unmarried (Table 4). 


\begin{tabular}{lcc}
\hline \multicolumn{3}{l}{ Table 4: Marital status of the respondents } \\
\hline Marital status & No. of respondents & \% age \\
\hline Married & 108 & 90 \\
Unmarried & 12 & 10 \\
Total & 120 & 100 \\
\hline
\end{tabular}

Source: primary probe, 2020

\subsection{Educational qualification of respondents}

Majority of the respondents had studied up to matriculation followed by higher secondary and graduation. The $38.33 \%$ respondents of matric level are higher among the group while $20 \%$ of the respondents were up to primary level only (Table 5).

\begin{tabular}{lcc}
\hline \multicolumn{3}{l}{ Table 5: Educational qualification of respondents } \\
\hline Education level & No. of respondents & $\%$ age \\
\hline Matriculation & 46 & 38.33 \\
Higher secondary & 34 & 28.33 \\
Graduation & 16 & 13.34 \\
Post graduation & 0 & 0 \\
others & 24 & 20 \\
Total & 120 & 100 \\
\hline
\end{tabular}

Source: primary probe, 2020

\subsection{Income of the respondents}

It shows from the tabular representation that The income of the respondent in the sepahijala district are based on the number of trees owned by the family. $41.67 \%$ of the respondents earns in between INR 20,000-50,000 month $^{-1}$ and $10.83 \%$ of the repondents were earning above INR 55,000 month $^{-1}$ or more than that (Table 6).

\begin{tabular}{lcc}
\hline \multicolumn{3}{l}{ Table 6: Income of the respondents } \\
\hline $\begin{array}{l}\text { Income } \\
\text { (INR Month }{ }^{-1} \text { ) }\end{array}$ & $\begin{array}{c}\text { No. of } \\
\text { respondents }\end{array}$ & $\begin{array}{c}\text { Frequency } \\
(\%)\end{array}$ \\
\hline Less than 20,000 & 34 & 28.33 \\
$20000-35000$ & 50 & 41.67 \\
$35000-55000$ & 23 & 19.17 \\
Above 55000 & 13 & 10.83 \\
Total & 120 & 100 \\
\hline
\end{tabular}

Source: primary probe, 2020

\subsection{Distribution of land holding among the respondents}

Most of the respondents were small scale farmers who were holding land in between 1-4 ha followed by marginal farmers (less than 1 ha), medium scale farmers (5-10 ha) and large scale farmers (above $10 \mathrm{ha}$ ). And only $2.5 \%$ of the respondents were large scale farmers amongst the respondents who hold land in above 10 ha (Table 7).

\begin{tabular}{lcc}
\hline \multicolumn{3}{l}{ Table 7: Distribution of land holding among the respondents } \\
\hline Land holdings $(\mathrm{Ha})$ & No. of respondents & $\%$ age \\
\hline$<1$ & 42 & 35 \\
$1-4$ & 68 & 56.67 \\
$5-10$ & 7 & 5.83 \\
Above 10 & 3 & 2.5 \\
Total & 120 & 100 \\
\hline
\end{tabular}

Source: primary probe, 2020

\subsection{Respondents opinions about rubber farming in Sepahijala district, Tripura}

It was observed that largely losses were being held with the attack of pest and diseases takes place in their field or farm followed by the increase in cost of labour, production and marketing problems, export of the final product, lesser marketable facilities and storage. The respondents were highly inclined to understand and avail the agri-clinical services in their respective farming business for the ultimate growth of their rubber farming. Thus the agri-clinical services improvise the management system of the rubber crop (Table 8).

3.9. Farmers responses towards the significances of Agriclinical services in providing training for the management of rubber plantation

Respondents attained training facility for the rubber farming which is provided in the block levels within the sepahijala district. Majority of the respondents attended the training while the others respondants were not aware about the training (Table 9).

\subsubsection{Clinical services availability within the locality}

Availability of the agri clinical services were barely available within the locality. Among the respondants, only the 16.67 $\%$ can avail the agri clinical services facility. Majority of the respondants was unable to find the inputs that were needed for the rubber farming (Table 10).

\subsection{Type of rubber processing done by the respondents}

Respondents usually sell the raw material in Ribbed smoked sheets (RSS) form by $85 \%$ of the respondents who seems to had higher margins than the latex creamy white. It was observed that only $15 \%$ of the respondents prefer to sell the product in latex creamy white (Table 11).

3.11. Respondent's opinion about consultation with the clinical services

Respondents require more consultation from agri-clinical services while some of the respondents don't want consultation from others and one-third of the respondents were neutral in the consultation process (Table 12).

\subsection{Challenges faced during the production of natural rubber}

It was observed that largely losses occurred due to the uncertainty of the environment followed by crop diseases, 


\begin{tabular}{|c|c|c|c|c|c|c|c|}
\hline \multirow[b]{2}{*}{ Farmers Opinions } & \multicolumn{5}{|c|}{ Weightage } & \multirow[t]{2}{*}{ *TWS } & \multirow[t]{2}{*}{ RANK } \\
\hline & $\begin{array}{l}\text { Strongly } \\
\text { Agree (5) }\end{array}$ & $\begin{array}{l}\text { Agree } \\
\text { (4) }\end{array}$ & $\begin{array}{c}\text { Neutral } \\
(3)\end{array}$ & $\begin{array}{l}\text { Disagree } \\
\text { (2) }\end{array}$ & $\begin{array}{l}\text { Strongly dis- } \\
\text { agree (1) }\end{array}$ & & \\
\hline There is an increase in the cost of labour & 36 & 42 & 42 & 0 & 0 & 474 & II \\
\hline $\begin{array}{l}\text { Storage facilities are major challenges that } \\
\text { are faced by rubber farmers }\end{array}$ & 0 & 42 & 48 & 20 & 10 & 362 & VI \\
\hline $\begin{array}{l}\text { Attack of pest and disease, outbreak of fire } \\
\text { and wind hazards affecting productions }\end{array}$ & 68 & 42 & 8 & 2 & 0 & ${ }^{* 536}$ & $\#^{\#}$ \\
\hline $\begin{array}{l}\text { Adequate market for primary rubber pro- } \\
\text { duction }\end{array}$ & 2 & 18 & 92 & 4 & 4 & 370 & V \\
\hline $\begin{array}{l}\text { Obtaining information about export markets } \\
\text { of rubber products is difficult }\end{array}$ & 34 & 46 & 28 & 8 & 4 & 458 & IV \\
\hline $\begin{array}{l}\text { You work collectively with other farmers } \\
\text { to solve farming problems (production and } \\
\text { marketing problems) }\end{array}$ & 34 & 44 & 38 & 2 & 2 & 466 & III \\
\hline
\end{tabular}

Source: primary probe, $2020 ;{ }^{*}$ TWS: Total Weightage Score Method; \#536: $68 * 5+42 * 4+8 * 3+2 * 2+0 * 1$; \#\#I: resulted on account of TWS score descendingly

Table 9: Farmers responses towards the significances of Agriclinical services in providing training for the management of rubber plantation

\begin{tabular}{lcc}
\hline Inclination & No. of respondents & $\%$ age \\
\hline Yes & 76 & 63.33 \\
No & 44 & 36.67 \\
Total & 120 & 100 \\
\hline
\end{tabular}

Source: primary probe, 2020

Table 10: Clinical services availability within the locality

\begin{tabular}{lcc}
\hline Status & No. of respondents & $\%$ age \\
\hline Yes & 20 & 16.67 \\
No & 100 & 83.33 \\
Total & 120 & 100 \\
\hline
\end{tabular}

Source: primary probe, 2020

Table 11: Type of rubber processing done by the respondents

Processed form No. of respondents \%age

\begin{tabular}{lcc}
\hline Ribbed Smoked Sheets & 102 & 85 \\
Latex Creamy White & 18 & 15 \\
Total & 120 & 100 \\
\hline
\end{tabular}

Source: primary probe, 2020

pest attack and others. The respondents were much worried about the destruction of the plants prevalently with different problems which occur seasonally (Table 13).

3.13. Respondents view on requiring the solutions from clinical services

Most of the respondents wants agri clinical sevices for their
Table 12: Respondent's opinion about consultation with the clinical services

\begin{tabular}{lcc}
\hline Inclination & No. of respondents & \%age \\
\hline Yes & 86 & 71.67 \\
No & 34 & 28.33 \\
Total & 120 & 100 \\
\hline
\end{tabular}

Source: primary probe, 2020

Table 13: Challenges faced during the production of natural rubber

\begin{tabular}{lcc}
\hline Issues & No. of respondents & \%age \\
Crop diseases & 40 & 33.33 \\
Pest Attack & 8 & 6.67 \\
Uncertainty & 66 & 55 \\
Others & 6 & 5 \\
Total & 120 & 100 \\
\hline
\end{tabular}

Source: primary probe, 2020

rubber farming and majority of the respondants said yes for solving the problems by $91.67 \%$ (Table 14).

Table 14: Respondents view on requiring the solutions from clinical services

\begin{tabular}{lcc}
\hline Inclination & No. of respondents & \%age \\
\hline Yes & 110 & 91.67 \\
No & 10 & 8.33 \\
Total & 120 & 100 \\
\hline
\end{tabular}

Source: primary probe, 2020 


\subsection{Awareness Level towards Agri-clinical services}

The awareness level features of agri-clinics upon certain statements by the respondents in the form of Total Weightage Score (TWS) and rankings. It was observed that higher awareness among the respondents places the first rank with highest to plant health and protection remedies i.e., 290 followed by pest management, field survey, crop consultancy, spray scheduling and others. The respondents were less aware about the diagnostic search of the crop where the TWS is 142 and ranking is last in the criteria (Table 15).

\begin{tabular}{|c|c|c|c|c|c|}
\hline \multirow[t]{2}{*}{ Clinical services } & \multicolumn{3}{|c|}{ Awareness Level } & \multirow[t]{2}{*}{${ }^{*}$ TWS } & \multirow[t]{2}{*}{ Rank } \\
\hline & $\begin{array}{l}\text { High } \\
\text { (3) }\end{array}$ & $\begin{array}{l}\text { Moderate } \\
\text { (2) }\end{array}$ & $\begin{array}{l}\text { Low } \\
(1)\end{array}$ & & \\
\hline Field survey & 28 & 84 & 08 & 260 & III \\
\hline Soil testing & 2 & 32 & 86 & 156 & IX \\
\hline Diagnostic search & 4 & 14 & 102 & 142 & $x$ \\
\hline Pest management & 54 & 50 & 16 & 278 & II \\
\hline Spray scheduling & 8 & 76 & 36 & 212 & V \\
\hline $\begin{array}{l}\text { Harvest standard- } \\
\text { ization }\end{array}$ & 4 & 78 & 38 & 206 & VI \\
\hline $\begin{array}{l}\text { Nutrient verifica- } \\
\text { tion }\end{array}$ & 14 & 18 & 88 & 166 & VIII \\
\hline $\begin{array}{l}\text { Plant health and } \\
\text { Protection rem- } \\
\text { edies }\end{array}$ & 66 & 38 & 16 & \#290 & $\# \#$ \\
\hline Crop consultancy & 24 & 80 & 16 & 248 & IV \\
\hline $\begin{array}{l}\text { Other institutional } \\
\text { services }\end{array}$ & 16 & 40 & 64 & 192 & VII \\
\hline
\end{tabular}

Source: primary probe, 2020; *: TWS: Total Weightage Score Method; \#290: 66*3+38*2+16*1; \#\# I: resulted on account of TWS score descendingly

\subsection{Perception level towards agri-clinical Services}

It was observed that the perception regarding clinical services helps in inducing plant knowledge and plant protection solutions i.e., 296 amongst the respondents who places it on $1^{\text {st }}$ rank followed by increases productivity, facilitates scientific knowledge, inculcate farm planning and crop management, extend the life of plant and crop and others. The farmers were less benefitted with alternative by-products of the rubber crop that is why the respondents answer the other crop benefits with lowest rank and TWS i.e., 160 (Table 16).

3.16. Significance level towards the application of agri-clinical services

The issues during the clinical services of the rubber crop were the limited number of clinical services in the locality or within the particular area, most of the respondent's given $1^{\text {st }}$ rank to limited number of clinical services provider with TWS i.e., 310 followed by low promotion and awareness, high cost, low scientific know how among farmers, No set standard quality of services and others. The other crop related issues with lowest rank and TWS i.e., 220 which showed that the farmers were having fewer grievances towards other crop related issues of the crop (Table 17).

\subsection{Suggestive opinions to improve the agri-clinical services}

It was observed that the farmers highly recommend the government subsidies for the rubber cultivation, most of the respondent's places the $1^{\text {st }}$ rank with highest TWS i.e. 334 to government subsidies followed by efforts to increase farmers participation, may provided through Agriculture Extension agencies, redressal mechanism over complaints against service providers, intensive promotion and farmers knowledge to be enriched, affordable clinical services and clinical services should be designed as per the farmers' need. The clinical services should be designed as per the farmers had given the lowest rank and TWS with 264 (Table 18).

Table 16: Perception level towards agri-clinical services

\begin{tabular}{|c|c|c|c|c|c|}
\hline \multirow[t]{2}{*}{ Clinical services } & \multicolumn{3}{|c|}{ Perception Level } & \multirow[t]{2}{*}{${ }^{*}$ TWS } & \multirow[t]{2}{*}{ Rank } \\
\hline & High (3) & Moderate (2) & Low (1) & & \\
\hline Helps in managing crop cost & 8 & 86 & 26 & 222 & VI \\
\hline Facilitates Scientific knowledge & 46 & 62 & 12 & 274 & III \\
\hline Extends the life of plant and crop & 6 & 96 & 18 & 228 & $\mathrm{~V}$ \\
\hline Increases productivity & 70 & 32 & 18 & 292 & II \\
\hline Decreaseswastivity & 4 & 66 & 50 & 194 & VII \\
\hline Inculcate farm planning and crop management & 18 & 78 & 24 & 234 & IV \\
\hline Induces plant knowledge and Plant protection solutions & 62 & 52 & 6 & \#296 & $\# \#$ \\
\hline Other crop benefits & 6 & 28 & 86 & 160 & VIII \\
\hline
\end{tabular}

Source: primary probe, 2020 ; * TWS: Total Weightage Score Method; \#296: $62 * 3+52 * 2+6 * 1$; \#\# I: resulted on account of TWS score descendingly 


\begin{tabular}{|c|c|c|c|c|c|}
\hline \multirow[t]{2}{*}{ Clinical services } & \multicolumn{3}{|c|}{ Significance level } & \multirow[t]{2}{*}{ "TWS } & \multirow[t]{2}{*}{ Rank } \\
\hline & High (3) & Moderate (2) & Low (1) & & \\
\hline High Cost & 48 & 72 & 0 & 288 & III \\
\hline Low credibility & 30 & 74 & 16 & 254 & VII \\
\hline No set standard quality of services & 58 & 38 & 24 & 274 & V \\
\hline unavailability as per the need & 26 & 72 & 22 & 244 & VIII \\
\hline Low promotion and Awareness & 60 & 50 & 10 & 290 & II \\
\hline Limited number of clinical service providers & 86 & 18 & 16 & "310 & \#\# \\
\hline Less Farmers participation & 26 & 84 & 10 & 256 & VI \\
\hline Low scientific know how among farmers & 52 & 54 & 14 & 278 & IV \\
\hline Other crop related issues & 16 & 68 & 36 & 220 & IX \\
\hline
\end{tabular}

Source: primary probe, 2020 ; * TWS: Total Weightage Score Method; \#310: $86 * 3+18 * 2+16 * 1$; \#\# I: resulted on account of TWS score descendingly

Table 18: Suggestive opinions to improve the agri-clinical services

\begin{tabular}{|c|c|c|c|c|c|}
\hline \multirow[t]{2}{*}{ Clinical services } & \multicolumn{3}{|c|}{ Recommendation Level } & \multirow[t]{2}{*}{ *TWS } & \multirow[t]{2}{*}{ Rank } \\
\hline & High (3) & Moderate (2) & Low (1) & & \\
\hline Government subsidies & 98 & 18 & 4 & \#334 & \#\#I \\
\hline May provided through Agriculture Extension Agencies & 68 & 44 & 8 & 300 & III \\
\hline Intensive promotion and Farmers knowledge to be enriched & 56 & 64 & 0 & 296 & V \\
\hline Clinical services should be designed as per the farmers' need & 32 & 80 & 8 & 264 & VII \\
\hline $\begin{array}{l}\text { Redressal mechanism over complaints against service pro- } \\
\text { viders }\end{array}$ & 64 & 50 & 6 & 298 & IV \\
\hline Affordable clinical services & 40 & 66 & 14 & 266 & VI \\
\hline Efforts to increase Farmers participation & 74 & 46 & 0 & 314 & II \\
\hline
\end{tabular}

Source: primary probe, 2020; * TWS: Total Weightage Score Method; \#334: $98 * 3+18 * 2+4 * 1$; \#\# I: resulted on account of TWS score descendingly

\section{Conclusion}

In rubber farming systems, significant variables should get more emphasis and care through formulating different development strategies and programmes for the rubber farmers. The awareness programmes should be conducted more frequently for better understanding of modern farm practices and to redress farming problems and related grievances. Farmers suggested that clinical services should be more often available to the farmers. The farmers should visit more clinical services with their causes and learn redressed mechanism. Use of clinical services may increase resource use efficiency and productivity and reduction in losses.

\section{References}

Bandyopadhay, S., Reza, S.K., Ray, P., Ramachandran, S., Mukhopadhyay, S., Sah, K.D., Nayak, D.C., Singh, S.K., Ray, S.K., 2018. Rubber growing soils of Bishalgarh block, Sepahijala district, Tripura: their characteristics, suitability and Management. ICAR-National Bureau of Soil and Land Use Planning, Salt Lake, Kolkata, West Bengal; ICAR-National Bureau of Soil Survey and Land Use Planning, Jamuguri Road, Jorhat, Assam 3(1), 180-184.

Bhowmik, I., 2006. A status report on rubber plantations in Tripura. Tripura Rubber Mission. SSRN Electronic Journal 1, 1-21.

Chouhan, P., Bhowmik, I., 2017. Labour market conditions of natural rubber plantations in Tripura, Department of Economics, Tripura University 14, 55-69.

Konyeha, S., Imouokhome, F. A., 2018. Development of a web based expert system for rubber crop disease diagnosis and management. Journal of Scientific Research 10(3), 239-248.

Masłowski, M., Miedzianowska, J., Strzelec, K., 2019. Natural rubber composites filled with crop residues as an alternative to vulcanizates with common fillers. Institute of Polymer and Dye Technology, Lodz University of 
Technology, Stefanowskiego 11, 972-978.

Reang, K., Biswas, A., Acharya, S.K., Marak, B.R., 2014. Determinants of small rubber growers' adoption behaviour in Dhalai district of Tripura. Dept. of Agricultural Extension, Bidhan Chandra Krishi Viswavidyalaya, Mohanpur, Nadia, West Bengal 10(2), 219-222.

Tetteh, E. N., Twum-Ampofo, K., Abunyewa, A., Acheampong, P. P., Nunoo, I., Berchie, J. N., Dzomeku, B. M., Adjei, A. E., Frimpong, F., Logah, V., MeLenya, C., Yeboah, S., Oteng-Darko, P., Acheampong, L. D., Tuffour, H., 2019. A logistic analysis of factors and perception of smallholder rubber farmers to intercrop: A case study involving rubber and plantain intercropping system in Ghana. Agricultural and Food Science Journal of Ghana 12, 1024-1039.

Vargas-Canales, J. M., Camacho-Vera, J. H., Pineda, J., MendozaCastillo, V. M., Fresnedo-Ramírez, J., López-García, S. M., Andrade-Saavedra, Z. X., 2019. Specialization and competitiveness of natural rubber (Hevea brasiliensis) production in Mexico. Revista Chapingo Serie Ciencias Forestales y del Ambiente 25(3), 425-439. 